NOTE

\title{
RETHINKING CRIMINAL JOINDER: AN ANALYSIS OF THE EMPIRICAL RESEARCH AND ITS IMPLICATIONS FOR JUSTICE
}

INTRODUCTION

This note reconsiders the rules of procedure governing criminal joinder in light of empirical studies on jury behavior. The discussion is limited to criminal joinder under the Federal Rules of Criminal Procedure. ${ }^{1}$ The analysis is relevant to criminal joinder in state prosecutions to the extent that the state rules are patterned after the Federal Rules of Criminal Procedure.

The procedural rules that govern federal criminal joinder and severance are Rules 8 (joinder) and 14 (severance) of the Federal Rules of Criminal Procedure. Rule 8 (a) provides standards for determining when a single defendant who has allegedly committed multiple criminal offenses may have the offenses joined in a single trial. Rule $8(\mathrm{~b})$ provides standards for evaluating when multiple defendants may be joined and tried together in a single trial. These rules "have achieved no more than rudimentary development and articulation." 2 Because of the underdevelopment of these rules and the existence of a body of empirical data to test the assumptions behind the rules, the time is ripe for a reconsideration of this area of criminal procedure.

This note considers joinder of offenses (Rule 8(a)) and joinder of defendants (Rule 8(b)) separately. Each discussion begins with an overview of the existing legal rules and the policy that underlies them. The next section deals with an analysis of the existing empirical research. A large amount of empirical data exists for joinder of offenses, while no empirical research has

Copyright (C) 1989 by Law and Contemporary Problems

1. The focus here is on criminal, rather than civil, joinder for two reasons. First, to date little empirical research has been done on juries and civil joinder. Of course, some of the data resulting from research on criminal joinder may also be applicable in a civil context. Nevertheless, there is a need for empirical research specifically addressed to the problems of joinder for the jury in a civil trial. For a promising beginning toward that end, see Horowitz \& Bordens, The Effects of Outlier Presence, Plaintiff Population Size, and Aggregation of Plaintiffs on Simulated Civil Jury Decisions, 12 LAW \& Hum. Behav. 209 (1988). Second, the issues of fairness and justice, while important in a civil trial, are not as urgent or compelling as they are when presented in a criminal proceeding. Thus, arguments for joinder on the basis of judicial economy may be given greater weight in a civil setting, when the countervailing issues of justice and fairness are not as forceful

2. 2 Standards For Criminal Justice, ch. 13, at 13-14 (2d ed. 1980). 
been done directly on joinder of defendants; as a result, the 8 (a) section of this note is more extensive than the $8(b)$ section.

In analyzing the $8(\mathrm{a})$ empirical data, I am not attempting to provide an exhaustive bibliographic survey of the research; the purpose is to discuss the application of the research to the federal rules governing criminal joinder as well as to suggest what issues need to be researched further. An example of the need for further research is that the empirical data show that a defendant faces a greater likelihood of conviction if he faces a single trial with joined offenses than if he is tried separately on all offenses, although the studies do not agree on exactly why this is so.

The next section in each part involves a discussion of the existing rules in light of this empirically demonstrated prejudice. The administration of the rules is examined to see whether some curative condition may mitigate this prejudice. The note concludes that the Federal Rules of Criminal Procedure dealing with criminal joinder are not applied in such a way as to cure prejudice to the defendant. Revisions of the Rule are proposed, and a call is made for a more equitable balancing by judges of the prejudice to defendants in their rulings on Rule 14 severance motions.

The issues raised by the current treatment of criminal joinder involve a number of constitutional considerations. A criminal trial may determine an individual's liberty, or even life, directly raising the issue of due process. ${ }^{3}$ The Constitution also guarantees individuals the right to trial by an impartial jury in all criminal proceedings. ${ }^{4}$ Thus, if joinder forces an individual to face a much greater likelihood of conviction than he would if he had been tried alone or had his offenses tried separately, joinder may not just be unfair; it may violate his constitutional rights.

\section{II}

\section{Joinder of OfFenses: Rule 8(A)}

A. The Legal Standards

The great bulk of empirical research on criminal joinder is focused on joinder of offenses, covered by Rule 8(a) of the Federal Rules of Criminal Procedure. Rule 8 provides the outer limits of what may be joined in a federal criminal action, ${ }^{5}$ allowing for joinder of offenses when the offenses charged are: (1) of the same or similar character; (2) based on the same act or transaction; or (3) based on two or more acts or transactions connected together or constituting parts of a common scheme or plan. ${ }^{6}$ The policies behind joinder are judicial economy and convenience. ${ }^{7}$ The government is

3. See U.S. Const, amend. V.

4. U.S. Const. amend. VI.

5. See United States v. Turkette, 632 F.2d 896, 906 (1st Cir. 1980), rev'd on other grounds, 452 U.S. 576 (1981). The First Circuit observed that joinder beyond Rule 8 is "per se impermissible" (citing King v. United States, 355 F.2d 700 (1st Cir. 1966)).

6. FED. R. Crim. P. 8(a).

7. See United States v. Swift, 809 F.2d 320, 322 (6th Cir. 1987). 
able to conserve funds, and joinder makes the trial process more convenient for witnesses and public authorities. ${ }^{8}$

The defendant himself may find a joined trial beneficial. He may prefer the convenience of a single trial as opposed to multiple trials, may have his case disposed of more quickly, or may benefit from concurrent sentencing. ${ }^{9}$ Conflicts arise, however, when a defendant believes that these potential advantages are outweighed by the prejudicial effects of a joined trial, and therefore seeks severance. It is in the context of disputes between the government and defendants about joined or severed trials that the issue of fairness to the defendant arises.

Rule 14 allows a trial judge to sever offenses joined under Rule 8 if the joinder is prejudicial to the defendant or the government. ${ }^{10}$ The trial judge is given broad discretion in weighing the possibility of prejudice to a party against the considerations of judicial economy. ${ }^{11}$ Furthermore, the concern with judicial economy is considered dominant to the extent that the defendant may have to show that the joinder was "manifestly prejudicial." 12

Federal courts have recognized four sources of prejudice that may harm a defendant in a joined trial: (1) The jury may become confused by the evidence across charges and fail to compartmentalize the evidence properly ("jury confusion" theory); ${ }^{13}$ (2) The jury may accumulate the evidence across charges, giving the evidence greater weight on one charge as a result of hearing evidence on other charges ("accumulation of evidence" theory);14 (3) The jury may infer that the defendant has a criminal disposition and find him guilty because of this disposition ("criminal inference" theory); ${ }^{15}$ (4) The defendant may become embarrassed or confounded in presenting separate defenses. ${ }^{16}$ Of these four possible sources of prejudice, the first three have been empirically tested. The results and implications of tests designed to measure these prejudices are discussed below.

\section{B. The Empirical Research}

1. General Methodological Review. Seven published studies have tested mock jurors' reactions to a trial where criminal offenses are joined: Kerr and Sawyers, ${ }^{17}$ Bordens, Horowitz, and Feldman, ${ }^{18}$ Bordens and Horowitz, ${ }^{19}$

8. Bruton v. United States, 391 U.S. 123, 134 (1968).

9. 2 Standards For Criminal Justice, supra note 2, Standard 13-2.1, commentary at 13-13.

10. Fed. R. Crim. P. 14.

11. United States v. Butler, 822 F.2d 1191, 1194 (D.C. Cir. 1987).

12. United States v. Armstrong, 621 F.2d 951, 954 (9th Cir. 1980).

13. See United States v. Foutz, 540 F.2d 733, 736 (4th Cir. 1976).

14. Id.

15. Id.

16. This argument for severance was presented in Cross v. United States, 335 F.2d 987, 989-90 (D.C. Cir. 1964). It has since been limited to cases where the defendant can show both important testimony to offer on one count and a strong need to refrain from testifying on another account. Baker v. United States, 401 F.2d 958, $976-78$ (D.C. Cir. 1968), cert. denied, 400 U.S. 965 (1970).

17. Kerr \& Sawyers, Independence of Multiple Verdicts Within a Trial by Mock Jurors, 10 Representative Res. Soc. Psychology 16 (1979). 
Tanford and Penrod (1982), ${ }^{20}$ Tanford and Penrod (1984), ${ }^{21}$ Tanford, Penrod, and Collins, ${ }^{22}$ and Greene and Loftus. ${ }^{23}$ Although each study is in certain ways methodologically distinct, ${ }^{24}$ the tests follow a general pattern.

First, the researcher uses a control group to pre-test the offenses to determine the percentage of guilty verdicts for each charge when presented in isolation. A group of mock jurors is then exposed to the evidence of the joined offenses. The jurors next vote on whether the defendant is guilty or not guilty, ${ }^{25}$ and answer further questions designed to illuminate the process that led them to their verdict. The jurors typically are asked to recall specific evidence offered during the trial (bearing on the jury confusion theory), rate the evidence (bearing on the accumulation of evidence theory), and rate the defendant for such things as dangerousness, likeability, believability, and honesty (bearing on the criminal inference theory). ${ }^{26}$ These ratings are compared with those of the control group. In some tests, instructions are given to the jury to determine the effectiveness of the instructions in a joined trial. ${ }^{27}$

2. Jury Confusion. Bordens and Horowitz found that jury confusion existed in a joined offense trial and found that the confusion was causally linked to biased verdicts against the defendants. ${ }^{28}$ Greene and Loftus listed three hypotheses that may account for juror confusion. ${ }^{29}$ Jurors' memories may become overloaded by a number of facts they find difficult to remember; jurors may integrate information from different sources; ${ }^{30}$ or jurors may remember only selective, salient information, serving to confirm their verdict. ${ }^{31}$ Greene and Loftus, however, found no significant juror confusion

18. Bordens, Horowitz \& Feldman, A Comparison of Verdicts Obtained in Severed and Joined Criminal Trials, 10 J. Applied Soc. Psychology 444 (1980).

19. Bordens \& Horowitz, Information Processing in Joined and Severed Trials, 13 J. Applied Soc. Psychology 351 (1983).

20. Tanford \& Penrod, Biases in Trials Involving Defendants Charged with Multiple Offenses, $12 \mathrm{~J}$. Applied Soc. Psychology 453 (1982).

21. Tanford \& Penrod, Social Inference Processes in Juror Judgments of Multiple-Offense Trials, $47 \mathrm{~J}$. Personality \& Soc. Psychology 749 (1984).

22. Tanford, Penrod \& Collins, Decision Making in Joined Criminal Trials: The Influence of Charge Similarity, Evidence Similarity, and Limiting Instructions, 9 LAW \& Hum. Benav. 319 (1985).

23. Greene \& Loftus, When Crimes are Joined at Trial, 9 Law \& Hum. Behav. 193 (1985).

24. For a summary of some of the important methodological differences, see infra Part II.B.5.

25. The researchers have used two different methods for measuring the guilty or not guilty choice. See Tanford \& Penrod, supra note 20; Tanford \& Penrod, supra note 21; Tanford, Penrod \& Collins, supra note 22 (each using a dichotomous guilty or not guilty choice). Compare Bordens, Horowitz \& Feldman, supra note 18; Bordens \& Horowitz, supra note 19; Greene \& Loftus, supra note 23 (each using a spectrum with a continuous measure of guilt allowing for more degrees of guilt).

26. Two different methods are used by the researchers to measure the amount of jury confusion. See Bordens \& Horowitz, supra note 19 (using a free recall task where jurors were asked to record what they remembered); Tanford \& Penrod, supra note 20. Compare Greene \& Loftus, supra note 23 (using a recognition task where jurors were asked by the researchers to answer specific questions about the evidence); Tanford \& Penrod, supra note 21; Tanford, Penrod \& Collins, supra note 22.

27. For a discussion of the results of these tests, see infra Part II.C.4.

28. Bordens \& Horowitz, supra note 19 , at 369 .

29. Greene \& Loftus, supra note 23, at 193-94.

30. See Bower, Black \& Turner, Scripts in Memory for Text, 11 Cognitive Psycholocy 177 (1979).

31. See Greene, Whodunit? Memory for Evidence in Text, 94 Aм. J. Psychology 479 (1981) 
in their study of joined criminal offenses. ${ }^{32}$ This result, however, may be attributable to the relative lack of evidence used in their study, or because they did not require the jurors to use a free recall task. ${ }^{33}$

Separate studies by Tanford and Penrod in $1982^{34}$ and $1984,{ }^{35}$ and by Tanford, Penrod, and Collins in 1985, ${ }^{36}$ all found some evidence of jury confusion of facts, but concluded that this confusion did not cause biased verdicts. Thus, the studies are not in complete agreement about whether juror confusion is a source of biased guilty verdicts in trials of joined criminal offenses. Most of the studies show that confusion by jurors is not related to biased guilty verdicts. Only one study found juror confusion to be a significant factor. ${ }^{37}$ This finding may be due to a methodological difference: The recall task may have been set up in a way that was directly related to guilt determinations. ${ }^{38}$ The conclusion that juror confusion is not related to biased verdicts is supported by research showing that memory of particular facts does not correlate strongly with general impressions. ${ }^{39}$ Future research into the exact nature of juror memory errors, which could resolve the methodological differences between the studies, would be useful in fully explaining the differences between the studies on the effect of jury confusion on guilty verdicts. ${ }^{40}$

3. Incorrect Accumulation (Weight) of the Evidence. Some studies have shown relatively slight support for this theory of bias. ${ }^{41}$ Bordens and Horowitz, however, found absolutely no evidence to support a theory that jurors allow

32. Greene \&c Loftus, supra note 23, at 205.

33. Bordens \& Horowitz, Joinder of Criminal Offenses: A Review of the Legal and Psychological Literature, 9 LAw \& Hum. Behav. 339, 345 (1985). Greene and Loftus admitted this possibility. Greene \& Loftus, supra note 23, at 205, 207.

34. Tanford \& Penrod, supra note 20, at 476.

35. Tanford \& Penrod, supra note 21 , at 762.

36. Tanford, Penrod \& Collins, supra note 22, at 334.

37. See Bordens \& Horowitz, supra note 19, at 369.

38. Tanford, Penrod \& Collins, supra note 22, at 323. Or, alternatively, the other studies may have underestimated the role confusion of evidence plays by failing to use a free recall task and by using a dichotomous and not continuous measure of guilt. For an argument to that effect, see Bordens \& Horowitz, supra note 33, at 344-46.

39. See Anderson \& Hubert, Effects of Concomitant Verbal Recall on Order Effects in Personality Impression Formation, 2 J. Verbal Learning \& Verbal Behav. 379 (1963); Dreben, Fiske \& Hastie, The Independence of Evaluative and Item Information: Behavior-based Impression Formation, 37 J. PERSONALITY \& Soc. Psychology 1758 (1979); Riskey, Verbal Memory Processes in Impression Formation. 5 J. Experimental Psychology: Hum. Learning \& Memory 271 (1979).

40. Bordens \& Horowitz, supra note 33, at 344-47.

41. See Tanford \& Penrod, supra note 20, at 476-77; Tanford \& Penrod, 'supra note 21, at 762; Tanford, Penrod \& Collins, supra note 22, at 334. In these studies, jurors were asked to rate on a numerical scale the prosecution's and the defendant's evidence. The ratings of the prosecution evidence were higher in joined than in severed cases, while the ratings of the defense evidence were lower in joined than in severed cases. For a further empirical study in a non-criminal joinder context supporting the notion that jurors' perception of the evidence is affected, see Saunders, Vidmar \& Hewitt, Eyewitness Testimony and the Discrediting Effect, in Evaluating Witness Evidence 57, 74 (S. Lloyd-Bostock \& B. Clifford eds. 1983) (study of eyewitness testimony) 
evidence of one charge to enforce the incriminating value of a second charge. ${ }^{42}$

These differences may be attributable to the methodological differences among the studies. ${ }^{43}$ Reconciling the studies is not a crucial issue, though, as no researcher maintains that accumulation of evidence is an important factor in producing biased verdicts.

4. Jury Inference of Defendant's Criminality. Studies have found relatively strong support for this theory of biased verdicts. ${ }^{44}$ The inference made by the jury that the defendant has a criminal personality type is consistent with the findings of Bordens and Horowitz.45 This theory is consistent with social science research concerning the "halo effect" (people infer that a person with one negative trait has other negative traits as well). ${ }^{46}$ Tanford and Penrod went so far as to propose a "path model" outlining the process by which criminal inferences made about the defendant influenced later jury judgments about the evidence. ${ }^{47}$

There are, however, limitations to the use of a path analysis based on a retrospective application of guilty verdicts. ${ }^{48}$ Future research is needed to determine whether a causal link exists between a guilty verdict and a criminal inference by the jury. ${ }^{49}$ Although it is clear that the two correlate, it is still possible that the criminal inference is made after the jury reaches its guilty verdict. ${ }^{50}$

5. General Joinder Effect Unanimously Found. Although the studies reach somewhat different conclusions about the particular causes of biases to defendants in trials of joined offenses (as shown above), the studies are unanimous in finding that defendants do face a greater likelihood of conviction if offenses are tried jointly rather than separately. ${ }^{51}$ Furthermore,

42. Bordens \& Horowitz, supra note 19, at 369 . Bordens and Horowitz asked jurors to write down their "thoughts" about the cases they heard and to rate the degree to which these thoughts favored the prosecution or the defense. There was no significant difference in ratings of antidefendant thoughts in joined versus severed cases.

43. Bordens \& Horowitz, supra note 33 , at 347-48.

44. See, e.g., Greene \& Loftus, supra note 23, at 204-05; Tanford \& Penrod, supra note 20, at 477;

Tanford \& Penrod, supra note 21, at 762-63; Tanford, Penrod \& Collins, supra note 22, at 334.

45. Bordens \& Horowitz, supra note 19, at 368.

46. Rosenberg \& Sedlak, Structural Representations of Implicit Personality Theory, in 6 Advances IN Experimental Social Psychology 235, 238 (L. Berkowitz ed. 1972).

47. Tanford \& Penrod, supra note 21 , at $760,763$.

48. See Bordens \& Horowitz, supra note 33, at 348-49.

49. Constructing an experiment to test for this causal connection would not be a difficult task. One could devise a study in which ratings of the defendant are taken at various points throughout a joined trial, for example. Bordens \& Horowitz, supra note 33, at 349.

50. Greene \& Loftus, supra note 23, at 204-05.

51. See, e.g., Bordens, Horowitz \& Feldman, supra note 18, at 453-54; Bordens \& Horowitz, supra note 19, at 366-68; Greene \& Loftus, supra note 23, at 204-05; Tanford \& Penrod, supra note 20, at 475; Tanford \& Penrod, supra note 21, at 761; Tanford, Penrod \& Collins, supra note 22, at 332. Kerr \& Sawyers, supra note 17, found evidence of a joinder effect, but did not provide a basis for comparing the result of the joined trial with the result if the defendant had been tried for each offense separately. 
the effect of joinder increases with the number of offenses charged. ${ }^{52} \mathrm{~A}$ cumulative compilation of all the joinder research findings shows that the effect of joinder of offenses is robust; ${ }^{53}$ there is a significantly greater likelihood of conviction for defendants.

These findings have been constant despite varying methodologies by the researchers. The defendant faced a greater likelihood of conviction under joinder of offenses whether the researchers used written summaries, ${ }^{54}$ audio tapes, ${ }^{55}$ or videotapes; ${ }^{56}$ whether there were two, three, or four offenses charged; 57 whether the jurors actually deliberated; 58 whether the jurors were undergraduate students or regular jurors previously summoned for jury duty; 59 and whether the researcher was able to use a full factorial design. ${ }^{60}$

\section{Particular Instances of the Joinder Effect.}

a. The effect of the order of offenses. Two studies have found that trials of joined offenses prejudice defendants by leading to a greater likelihood of conviction, but only on the first offense before the jury. ${ }^{61}$ Other studies, however, have consistently found no increased proportion of convictions on the first charge as opposed to later charges. ${ }^{62}$ Tanford, Penrod, and Collins actually found a greater proportion of convictions on the later offenses charged. ${ }^{63}$

There is no consistent evidence of the effect of joinder being influenced by the order in which offenses are presented. The different findings by the researchers may result from the use of different case studies and the varying strengths of the cases employed by the researchers. ${ }^{64}$

b. Weaker cases. Kerr and Sawyers ${ }^{65}$ and Tanford, Penrod, and Collins 66 found that the joinder effect was greater when cases are weak. Among a series of joined offenses, a control group was least likely to convict a defendant in a separate trial of the offense that had the greatest proportionate variance from the control group verdict when tried with other crimes.

52. Tanford \& Penrod, supra note 20, at 475.

53. Tanford, Penrod \& Collins, supra note 22, at 332-33.

54. Greene \& Loftus, supra note 23, at 194-95; Kerr \& Sawyers, supra note 17, at 18.

55. Bordens, Horowitz \& Feldman, supra note 18, at 449; Bordens \& Horowitz, supra note 19 , at 354.

56. Tanford \& Penrod, supra note 21, at 754-55.

57. Tanford \& Penrod, supra note 20, at 458-59.

58. Tanford \& Penrod, supra note 21 , at 755.

59. Id. at 752-53.

60. Tanford, Penrod \& Collins, supra note 22, at 324. For a discussion of factorial designs and their usefulness in empirical research, see J. Carlsmith, P. Ellsworth \& E. Aronson, MEthods of Research in Social Psychology, 243-55 (1976). 366 .

61. Bordens, Horowitz \& Feldman, supra note 18, at 453; Bordens \& Horowitz, supra note 19, at

62. See Greene \& Loftus, supra note 23; Kerr \& Sawyers, supra note 17; Tanford \& Penrod, supra note 20 .

63. Tanford, Penrod \& Collins, supra note 22, at 333.

64. Id.

65. Kerr \& Sawyers, supra note 17.

66. Tanford, Penrod \& Collins, supra note 22, at 333. 
c. Similar offenses. Separate studies have found that the effect of joinder is stronger when the cases joined were similar as opposed to dissimilar. ${ }^{67}$ In other words, there was a greater variance from control group severed verdicts when two rape charges against a defendant were tried together (joinder under the similar offense provision of Rule 8(a)), than when a rape and a murder charge were joined against a defendant (joined because they arose under the same plan).

7. Summary. The empirical data unequivocally show that the probability of a defendant being convicted significantly increases if offenses are joined rather than tried separately. The data are not presently conclusive as to the exact cause of the joinder effect. It appears to be based on an inference by the jury that the defendant is a criminal, but this has not yet been proved to be a causal link. A less likely possibility that cannot be conclusively rejected yet is that jurors' memories become confused in joined trials, and that, as a result, jurors do not properly segregate the information they are given.

It is crucial to determine exactly what causes jurors to reach a greater proportion of guilty verdicts in trials of joined offenses. If the joinder effect occurs because jurors' cognitive processes are overwhelmed, the problem may be solved through some form of case management, such as multiple juries, juror instructions, ${ }^{68}$ and juror education, which would aid the jury in segregating the facts. ${ }^{69}$ If, however, the effect is based on an inference of criminality made by the jury, the problem is unlikely to be solved through case management. The only solution might well be a less frequent and more circumspect use of joinder.

\section{The Implications of the Empirical Research on the Law of Joinder of Offenses}

1. Rule 8(a). The provision of Rule 8(a) allowing for the joinder of similar but unrelated offenses should be modified. Similar-offense joinder is the most controversial of the 8 (a) joinder provisions; it is not allowed in the great majority of states. ${ }^{70}$ The argument for judicial economy is particularly unpersuasive for similar-offense joinder. Since the offenses are distinct, the joined trial will often require separate evidence and witnesses. ${ }^{71}$ The only time savings would be realized in empanelling the jury and presenting background evidence about the defendant. ${ }^{72}$ These minor time savings seem

67. See Bordens \& Horowitz, supra note 19, at 366; Tanford, Penrod \& Collins, supra note 22, at 333.

68. See infra Part II.C.4. For discussion of an empirical study showing that clearer jury instructions may reduce the number of guilty verdicts, see Severance \& Loftus, Improving the Ability of Jurors to Comprehend and Apply Criminal Jury Instructions, 17 LAw \& Soc'y Rev. 153, 194-96 (1982).

69. Bordens \& Horowitz, supra note 33, at 350-51.

70. Note, Joint and Single Trials Under Rules 8 and 14 of the Federal Rules of Criminal Procedure, 74 YALE L.J. 553, 560 (1965).

71. Id.

72. Id. 
to be greatly outweighed by the prejudice against the defendant shown to exist by the empirical data in joined trials. The prejudice may be particularly great since the offenses are similar. ${ }^{73}$ Furthermore, the legislative history of similar-offense joinder undermines the rationale of judicial economy. Similaroffense joinder was not enacted to save time; it was a by-product of the regulation of marshal's fees. ${ }^{74}$

Similar-offense joinder is particularly pernicious because it invites an end run around Federal Rule of Evidence 404 (evidence of other crimes is prohibited if it is offered to prove criminal disposition). ${ }^{75}$ After hearing evidence of other crimes, a jury may make the impermissible inference that a defendant is a criminal on the basis of the multiple crimes before it, and convict on that basis. The empirical data strongly support the proposition that juries do this. ${ }^{76}$ Courts, too, have recognized this danger. ${ }^{77}$ The judicial response in most cases, however, has often been to allow the joinder and rely upon a jury instruction to eliminate any prejudice. ${ }^{78}$ The inadequacy of jury instructions to effect this result is dealt with below.

Rule 8(a) should be revised to protect defendants against the prejudices involved in similar-offense joinder. Perhaps similar-offense joinder should be abolished altogether, as it has been in many states, in light of its minimal time savings and proven prejudice. Alternatively, recognizing that a defendant may prefer a joined trial, the rules could allow the unlimited joinder of unrelated offenses if a defendant were granted an absolute right to severance, as the ABA Task Force on Joinder and Severance has proposed. ${ }^{79}$ Finally, the minimum acceptable revision would be to allow for similar-offense joinder only when the government can clearly show that the evidence introduced would be admissible anyway at separate trials under an exception to Rule 404 (b) ${ }^{80}$

2. Rule $8($ a) Appeals-Misjoinder. The issue whether a trial judge improperly joined offenses under Rule $8(a)$ is a question of law, reviewable de novo on appeal. $^{81}$ An appellate court, however, may find that even when joinder is improper, it falls under the harmless error rule 52(a) of the Federal Rules of Criminal Procedure, and does not require reversal. ${ }^{82}$ The empirical data ${ }^{83}$

73. See supra Part II.B.6(c).

74. See Note, supra note 70 , at $560 \mathrm{n} .37$ and legislative history discussed therein.

75. See Fed. R. Evid. 404(b).

76. See supra Part II.B.4.

77. See, e.g., United States v. Foutz, 540 F.2d 733, 736-37 (4th Cir. 1976); Drew v. United States, 331 F.2d 85, 89-90 (D.C. Cir. 1964).

78. See discussion in Drew, 331 F.2d at 91 .

79. 2 Standards For Criminal Justice, supra note 2, Standard 13-3.1(a).

80. See Note, Joinder of Criminal Offenses in Nebraska: Judicial Discretion v. Fair and Impartial Trial, 56 Neb. L. Rev. 399, 406 (1977). The court in Foutz, 540 F.2d at 736-38, relied on such a test in finding prejudicial joinder and reversing a conviction.

81. See United States v. Fagan, 821 F.2d 1002, 1006 (5th Cir. 1987), cert. denied, 484 U.S. 1005 (1988).

82. United States v. Lane, 474 U.S. 438, 449 (1986); see also United States v. Lueth, 807 F.2d 719,730 n.6 (8th Cir. 1986) (harmless error where judge gave cautionary instructions to the jury).

83. See supra Part II.B. 
should cause appellate courts to be much more cautious in declaring misjoinder "harmless."

3. Rule 14 Motions for Severance. Although Rule 14 allows a party to obtain relief from prejudicial joinder, a defendant faces numerous difficulties in obtaining severance. Procedurally, there is never a good time to claim unfair joinder. Before trial, such a claim may seem speculative, during the trial, disruptive, and after the trial, harmless error ${ }^{84}$ The trial judge is allowed broad discretion in weighing the possibility of prejudice against the consideration of efficiency. ${ }^{85}$ This discretion frequently means that a trial judge will fail to articulate satisfactorily the reasons for his decision on joinder and severance. ${ }^{86}$

The standards for overturning a trial judge's Rule 14 refusal to sever are imposing. A defendant must show that the trial court's refusal to sever was an abuse of discretion. ${ }^{87}$ A defendant must show specifically how he would be prejudiced; 88 he cannot merely assert prejudice in the abstract. ${ }^{89}$ The prejudice must be so compelling that it rises to the level of depriving him of his right to a fair trial. ${ }^{90}$ The mere allegation that he would stand a better chance of acquittal if granted severance is insufficient to meet these burdens. ${ }^{91}$

In the case of appeals after a joined trial, appellate courts are particularly reluctant to engage in speculation regarding a jury's motivation during deliberations. ${ }^{92}$ Frequently, courts seem content with a cliched application of the harmless error rule: "A defendant is entitled to a fair trial but not a perfect one." 93

The overwhelming empirical data demonstrating the possibility of

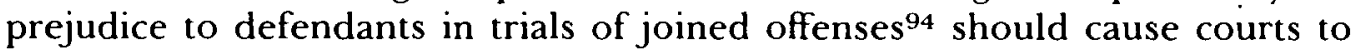
ease the burden of defendants seeking severance.

84. Dawson, Joint Trials of Defendants in Criminal Cases: An Analysis of Efficiencies and Prejudices, 77 MiCh. L. Rev. 1379, 1410 (1979).

85. See United States v. Butler, 822 F.2d 1191, 1194 (D.C. Cir. 1987).

86. 2 Standards For Criminal Justice, supra note 2, Standard 13-5.1, commentary at 13-46. The need for a meaningful basis of review and guidance for trial courts on the basis of decisions made in previous cases led the ABA Task Force to propose that courts be required to make a record of their reasons for granting or denying severance motions. Id.

87. See United States v. Thomas, 676 F.2d 239, 243 (7th Cir. 1980), cert. denied, 450 U.S. 931 (198I).

88. United States v. Mitchell, 788 F.2d 1232, 1237 (7th Cir. 1986).

89. United States v. Markey, 693 F.2d 594, 597 (6th Cir. 1982).

90. United States v. Burton, 724 F.2d 1283, 1287 (7th Cir. 1984); United States v. Arbelaez, 719 F.2d 1453, 1460 (9th Cir. 1983), cert. denied, 467 U.S. 1255 (1984). The same standards apply when a defendant seeks habeas corpus relief for a state's improper refusal to sever. See, e.g., Panzavecchia v. Wainwright, 658 F.2d 337, $341-42$ (5th Cir. 1981).

91. United States v. Butler, 792 F.2d 1528, 1534 (11th Cir.), cert. denied, 479 U.S. 933 (1986)

(Butler dealt with joined defendants, not joined offenses, however.).

92. See Dawson, supra note 84 , at 1402.

93. Lutwak v. United States, 344 U.S. 604, 619 (1953).

94. See supra Part II.B.5. 
4. The Current Judicial Approach of Curative Conditions. The legal system, without reference to empirical data, recognizes the dangers of prejudice when offenses are joined. In response, courts have relied upon several curative conditions, which, if they exist, may justify a refusal to sever under Rule 14 . These conditions include: (1) limiting instructions to the jury; ${ }^{95}$ (2) the ability of the jury to compartmentalize the evidence ${ }^{96}$ (sometimes shown through an acquittal on any count) $;^{97}$ (3) the presence of overwhelming guilt in the record;98 and (4) the use of concurrent sentencing. ${ }^{99}$ The law today assumes that these conditions may be adequate to rectify any prejudices defendants suffer because of joinder. ${ }^{100}$ These conditions need to be rethought in light of the empirical data.

The conditions of overwhelming guilt in the record and concurrent sentencing are controversial at best. Applying a test of overwhelming guilt is not responsive to Rule 14, provides no discretionary guidance, and invites abuse in the form of a solely pro forma review by the appellate court. ${ }^{101}$ Concurrent sentencing may be of little consolation to a defendant who, without joinder, may have been acquitted of all offenses or received lesser or suspended sentences on each count. ${ }^{102}$ The effectiveness of these curative conditions is especially dubious in light of the significant evidence on the prejudicial effects of joinder.

Limiting instructions are a pervasive means by which the law seeks to control the potentially prejudicial damage that occurs during the course of a trial. The Supreme Court itself has recognized, however, that there are limitations to the value of jury instructions. ${ }^{103}$ These limitations need to be re-evaluated in light of the empirical data on both limiting instructions and criminal joinder.

General empirical research on jury instructions casts doubt upon their effectiveness in curing a jury's prejudice. Lind concluded that while some

95. United States v. Burgess, 791 F.2d 676, 679 (9th Cir. 1986); Breeland v. Blackburn, 786 F.2d 1239, $1241-42$ (5th Cir. 1986).

96. United States v. Daniels, 770 F.2d 1111, 1117-18 (D.C. Cir. 1985); Drew v. United States, 331 F.2d 91 (D.C. Cir. 1964).

97. United States v. Thiron, 813 F.2d 146, 155 (8th Cir. 1987); States v. Buishas, 791 F.2d 1310, 1314-15 (7th Cir. 1986).

98. Oliver v. Dugger, 785 F.2d 949, $951-52$ (1 l th Cir.), cert. denied, 479 U.S. 859 (1986); Burgess, 791 F.2d at 679.

99. Patterson v. United States, 324 F.2d 310 (5th Cir. 1963).

100: The Fifth Circuit reflected this attitude:

We concede that joint trials, and especially those involving many defendants, carry substantial risks of manifest unfairness. At the same time, it is beyond question that such trials are now an accepted and even necessary aspect of our judicial system. This is because our system will tolerate the risk of unfairness so long as careful efforts are made to ensure that the inequities are kept in check.

United States v. McLaurin, 557 F.2d 1064, 1074 (5th Cir.), cert. denied, 434 U.S. 1020 (1977).

101. Note, supra note 70, at 555-56.

102. Id. at 555 .

103. In Bruton v. United States, 391 U.S. 123, 135 (1968), the Court stated: "There are some contexts in which the risk that the jury will not, or cannot, follow instructions is so great, and the consequence of failure so vital to the defendant, that the practical and human limitations of the jury system cannot be ignored." 
instructions were followed by a jury, many were ignored.104 Kassin and Wrightsman found that the effect of instructions varied with the point in the trial at which they were given. ${ }^{105}$ One study found that only one out of eighteen jurors remembered the instructions well enough to follow them. ${ }^{106}$ Finally, there is evidence that jurors have difficulty understanding the instructions, ${ }^{107}$ making them difficult to apply, even if jurors remember the instructions and try to apply them in spite of the prejudicial information they have heard.

Some of the empirical studies on criminal joinder also tested the effects of limiting instructions in joined trials. Greene and Loftus found jury instructions to have no curative effect on the jury. ${ }^{108}$ Tanford and Penrod also found them to have no influence in a mock trial of joined offenses. ${ }^{109}$ Tanford, Penrod, and Collins did find jury instructions to be effective when the researchers made a major effort to use non-standard instructions. 110

Thus, curative instructions, as used by the courts today, are insufficient to counter the demonstrated prejudical effects of joinder. The confidence that judges frequently invest in this curative condition when allowing joinder is rendered dubious by the empirical data. Although one study provides hope that in certain contexts limiting instructions can be effective to counter the prejudicial effects of joinder, it is an inadequate basis for justifying the current system, with its demonstrated unfairness to defendants. If courts can devise new instructions that empirically prove to be effective, a liberal attitude toward joinder of offenses might be justified. Until then, however, courts should not take comfort in the fact that a defendant with joined offenses received curative jury instructions.

A judicial determination that the jury was able to compartmentalize the evidence is also of questionable curative value in light of the empirical data. The fact that a defendant is acquitted on one charge should not be conclusive; without joinder, the defendant might have been acquitted on all counts." 11

If indeed the cognitive process is not related to verdicts in joined trials, as the data suggest, 112 then a judicial finding of compartmentalization is

104. Lind, The Psychology of Courtroom Procedure, in The Psychology of the Courtroom 13 (N. Kerr \& R. Bray eds. 1982).

105. Kassin \& Wrightsman, On the Requirements of Proof: The Timing of Judicial Instructions and Mock Juror Verdicls, 37 J. Personality \& Soc. Psychology 1877 (1979).

106. Hoffman \& Brodley, Jurors on Trial, 17 Mo. L. Rev. 235, 245 (1952).

107. See, e.g., A. Elwork, B. Sales \& J. Alfini, Making Jury Instructions Understandable (1982). This study found an average of about $50 \%$ comprehension, but the exact percentage varies.

108. Greene \& Loftus, supra note 23, at 205-06. Greene and Loftus used actual Washington State multiple offense instructions, and found them ineffective regardless of when they were used in the trial (contra Kassin \& Wrightsman, supra note 105).

109. Tanford \& Penrod, supra note 21 , at 761.

110. Tanford, Penrod \& Collins, supra note 22, at 335 . This result is somewhat limited by the use of elaborate instructions, the use of undergraduates instead of representative jurors, and the fact that the instructions, while they influenced verdicts, failed to influence the memory, evidence, strength, and perception of the evidence reported by the jurors. Id. at 334 .

111. Note, supra note 70, at 555.

112. See supra Part II.B.2. 
irrelevant. If further research were to show that the cognitive process of jurors does cause biased verdicts in trials of joined offenses, compartmentalization would be relevant. The inquiry would then shift to finding solutions, such as empanelling multiple juries, allowing note-taking, or improving limiting instructions, ${ }^{13}$ which could be shown empirically to aid juror cognition and produce unbiased verdicts.

III

JoINDER OF DEFENDANTS: Rule 8(B)

\section{A. The Legal Standards}

The outer limits of the joinder of criminal defendants is set by Rule $8(\mathrm{~b})$ of the Federal Rules of Criminal Procedure. Rule 8(b) allows the joinder of two or more defendants "if they are alleged to have participated in the same act or transaction or in the same series of acts or transactions" that constitute a criminal offense. ${ }^{14}$ If the joinder is based on the broader provision of being part of a series of acts or transactions, there must at least be a logical relationship between the offenses charged.115 The standard for joining defendants is even broader under the Racketeer Influenced and Corrupt Organizations Act ("RICO")."16 Under RICO, unrelated crimes or conspiracies may be joined if they are shown to have furthered the affairs of an enterprise (defined in RICO). ${ }^{117}$

The policy behind allowing joinder of defendants is principally an efficiency concern, ${ }^{118}$ although a fairness rationale of consistency of result, and a concern for giving the jury an "overall" view, are sometimes articulated as well. ${ }^{119}$

Rule 14, which by implication limits severance to cases where compelling prejudice is demonstrated, applies to joinder of defendants as well as to joinder of offenses. ${ }^{120}$ Courts have recognized a number of circumstances where compelling prejudice exists as a matter of law. ${ }^{121}$ These examples are

113. See Calo, Joint Trials, Spillover Prejudice, and the Ineffectiveness of a Bare Limiting Instruction, 9 AM. J. Trial Advoc. 21, 37-41 (1985).

114. See Fed. R. CRim. P. 8(b).

115. See United States v. Fischl, 797 F.2d 306, 313 (6th Cir. 1986) (court held that defendant Fischl's participation in a kickback scheme and cover-up was "inextricably intertwined" with his codefendant's offenses).

116. 18 U.S.C. $\$ \$ 1961-1968$ (1982).

117. See United States v. Caporale, 806 F.2d 1487, 1510 (1 lth Cir. 1986), cert. denied, 483 U.S. 1021 (1987); United States v. Manzella, 782 F.2d 533, 540 (5th Cir.), cert. denied, 476 U.S. 1123 (1986).

118. See Parker v. United States, 404 F.2d 1193, 1196 (9th Cir. 1968), cert. denied, 394 U.S. 1004 (1969). For a critical analysis of this efficiency justification, arguing that the supposed efficiencies of trials of joined defendants are grossly exaggerated or nonexistent, see Dawson, supra note 84 , at $1381-91$.

119. See Bruton v. United States, 391 U.S. 123, 143 (1968) (White, J., dissenting). For a critical discussion of the nonefficiency justifications of joined trials, see Dawson, supra note 84, at 1391-97.

120. See supra Part II.C.3.

121. These instances are: (1) mutually exclusive or antagonistic defenses among defendants, see, e.g., United States v. Gonzales, 804 F.2d 691,695 (1 l th Cir. 1986); but see United States v. Carrion, 
limited, however. Courts often refuse to find bias against joined defendants to be compelling. ${ }^{122}$ The courts also often rely on the existence of the same curative conditions that are used in an $8(\mathrm{a})$ analysis. ${ }^{123}$

\section{B. The Empirical Research}

No empirical research has been published to date dealing with the potential for prejudice in trials of joined criminal defendants. Given the importance of Rule 8(b) and the frequency with which it is used to try multiple defendants, this issue should be a priority for future empirical studies.

Nevertheless some of the data from the $8(a)$ research are applicable to trials of joined defendants. The data on the effect (or lack of effect) of cautionary jury instructions, ${ }^{124}$ the evidence about the jury's formation of a criminal inference, ${ }^{125}$ and the data on juror confusion ${ }^{126}$ (if proven to be relevant by future research) will all be important in empirically analyzing potential prejudices in trials of joined defendants. In addition, the fact that the joinder effect appears stronger in weak cases ${ }^{127}$ may mean that minor figures in a joint trial suffer particular prejudice.

There is some social psychology research that may have bearing on the fairness of trials of more than one defendant. Wilder found a strong tendency for people to attribute similarity to all group members when people are presented as a group. ${ }^{128}$ There is also a tendency for people to attribute group characteristics in the direction of the most extreme example presented

809 F.2d 1120, 1125 (5th Cir. 1987) (denial of severance upheld because defenses interpreted as not mutually exclusive); (2) a codefendant's refusal to offer exculpatory testimony in a joint trial because of fear of self-incrimination, see United States v. Williams, 809 F.2d 1072, 1084 (5th Cir.), cert. denied, 484 U.S. 896 (1987) (severance denied unless defendant can make certain showings); and (3) a codefendant's having made out of court statements that would incriminate the defendant but leave the defendant without the chance to cross-examine the codefendant, see Bruton, 391 U.S. at 126.

122. Courts have refused to find compelling prejudice in the following situations: (1) when only a small percentage of evidence is directed against one defendant and he may be hurt by "spillover prejudice" from evidence against co-defendants, see United States v. Vaccaro, 816 F.2d 443, 449 (9th Cir.), cert. denied, 484 U.S. 928 (1987); United States v. Fortna, 796 F.2d 724, 737-38 (5th Cir.), cert. denied, 479 U.S. 950 (1986); (2) when evidence of a codefendant's prior acts or prior criminal record is introduced, see United States v. Davis, 787 F.2d 1501, 1504 (1 lth Cir.), cert. denied, 479 U.S. 852 (1986); and (3) when joint defendants elect different (but not mutually exclusive or antagonistic) trial strategies, see Calo, supra note 113 , at $30-31$.

123. See, e.g., United States v. Lane, 474 U.S. 438 (1986) (presence of overwhelming evidence of guilt in the record); United States v. Molinares Charris, 822 F.2d 1213, 1221 (1st Cir. 1987) (adequate limiting instructions given); United States v. Hughes, 817 F.2d 268, 272 (5th Cir.), cert. denied, 484 U.S. 858 (1987) (jury able to compartmentalize); United States v. Moreno Morales, 815 F.2d 725, 742 (1st Cir.), cert. denied, 484 U.S. 966 (1987) (acquittal on 8 of 48 counts sufficient evidence of compartmentalization).

124. See supra Part II.C.4.

125. See supra Part II.B.4.

126. See supra Part II.B.2.

127. See supra Part II.B.6(b).

128. Wilder, Perceiving Persons as a Group: Effects on Attributions of Causality and Beliefs, 41 Soc. Psychology 13, 21 (1978). 
to them. ${ }^{129}$ This tendency was found to exist among jurors in a civil trial who were presented with aggregated plaintiffs. ${ }^{130}$

These data, and the 8 (a) research, suggest that jurors are biased against joined defendants in a trial under Rule $8(\mathrm{~b})$, and that the existing curative conditions are insufficient to cure the prejudice. This, however, is no more than a prediction in the absence of specific experiments designed to test for the potential prejudicial effects of Rule $8(\mathrm{~b})$ joinder. If the data show, as expected, that significant prejudices exist for joined defendants, courts should lower the standards they require of defendants to show compelling prejudice under $8(b)$, just as they should do under $8(a)$ for joinder of offenses.

\section{IV}

\section{CONCLUSION}

Although further research is needed to pinpoint the exact cause of bias against defendants with offenses joined under Rule 8(a), and although this further research may have a profound impact in determining how to eliminate the problem caused by joinder of offenses (less frequent use of joinder or steps to aid the cognitive process of jurors), this is no excuse for present idleness. Research has clearly shown that defendants face a significantly greater probability of conviction if offenses charged against them are tried jointly instead of separately. Both trial and appellate courts should be more willing to grant severance in light of strong research findings of prejudice against the 8 (a) defendant.

There are not enough empirical data available at the moment to justify recommending widespread changes in joinder under Rule 8(b). The data indirectly applicable to Rule 8 (b), however, indicate that courts should be more cautious about joining defendants and more reluctant to dismiss their severance motions.

In light of the Constitution's guarantee to a defendant of due process and an impartial trial, Rule $8(a)$ should be rewritten by legislators and administered differently by judges to abolish or at least modify similar-offense joinder, and to balance a greater concern for fairness to the defendant with a less heavy-handed emphasis on expense, efficiency, and convenience. ${ }^{131}$

\section{James Farrin}

129. See Leon, Oden \& Anderson, Functional Measurements of Social Values, 27 J. Personality \& Soc. Psychology 301, 307 (1973).

130. See Horowitz \& Bordens, supra note 1 .

131. The ABA Task Force on Joinder and Severance, using Model Penal Code section $5.03(4)$ (b)(iii) language, drafted a standard for severance of offenses which improves on Rule 8(a) by expressing a priority towards fairness that would help guide courts in exercising their discretion in severance motions.

Standard 13-3.1 Severance of Offenses.

(b) The court, on the application of either the prosecuting attorney or the defendant, should grant a severance of related offenses:

(i) before trial, whenever severance is deemed appropriate to promote a fair determination of the defendant's guilt or innocence of each offense; or 
(ii) during trial, whenever, upon the consent of the defendant or upon a finding or manifest necessity, severance is deemed necessary to achieve a fair determination of the defendant's guilt or innocence of each offense.

2 Standards for Criminal Justice, supra note 2. 